\title{
Auditor Judgements after Withdrawal of the Materiality Accounting Standard in Australia
}

\author{
Raul David (D) and Indra Abeysekera *(D) \\ Discipline of Accounting and Finance, Charles Darwin University, Darwin, NT 0800, Australia; \\ raul.david@cdu.edu.au \\ * Correspondence: indraabeysekera@gmail.com; Tel.: +61-(0)417-405-399
}

Citation: David, Raul, and Indra

Abeysekera. 2021. Auditor

Judgements after Withdrawal of the Materiality Accounting Standard in Australia. Journal of Risk and Financial Management 14: 268. https:// doi.org/10.3390/jrfm14060268

Academic Editor: Juan

Manuel Ramon-Jeronimo

Received: 7 May 2021

Accepted: 8 June 2021

Published: 13 June 2021

Publisher's Note: MDPI stays neutral with regard to jurisdictional claims in published maps and institutional affiliations.

Copyright: (c) 2021 by the authors. Licensee MDPI, Basel, Switzerland. This article is an open access article distributed under the terms and conditions of the Creative Commons Attribution (CC BY) license (https:// creativecommons.org/licenses/by/ $4.0 /)$.

\begin{abstract}
The concept of materiality, originating in the accounting domain and applied in the auditing domain, is an essential tool for improving audit quality. A renewed interest in materiality research emerged in Australia after submitting Exposure Draft no. 243 by the Australian Accounting Standards Board (AASB) proposing the withdrawal of AASB 1031 Materiality, which became effective in July 2015. The purpose of this paper is to review the audit literature to examine how the materiality concept is located in the regulatory framework, the standards and guidance that support the application of this concept, and research undertaken using different research methods. As our review reveals significant gaps in recent research on the subject, gaps need to be addressed. The paper concludes by proposing research propositions that fit into the audit triangle for materiality research developed in this paper.
\end{abstract}

Keywords: AASB 101; AASB 108; AASB 1031; errors; materiality; material misstatements; omissions

\section{Introduction}

What is material is that which matters. Accounting and auditing terminologies refer to material as minimising errors and misstatements in financial Information. Materiality is about tolerating these. A lower tolerance (or lower materiality) of them leads to more accurate accounting information and more robust audits (Houghton et al. 2011). Materiality is an accounting concept applied by the accounting profession to evaluate the significance of accounting events and transactions. The resulting decision can influence audited financial statements and users' decision-making (ICAEW 2017). Attention to materiality is important for auditors as part of taking due care on their work (Edgley 2014; Messier et al. 2005). The persistent interest in the concept of materiality arose with concerns from the Securities and Exchange Commission (SEC), the Sarbanes-Oxley Act (SOX), the International Accounting Standards Board (IASB), and the International Auditing and Assurance Standards Board (IAASB). These concerns led to amended standards on materiality (Messier et al. 2005).

The purpose of this paper is to review the audit literature to examine how the materiality concept is located in the regulatory framework, the standards and guidance that support the application of this concept, and research undertaken using different research methods. In Australia, the concept of materiality judgements received auditors' closer attention with the submission of Exposure Draft (ED) no. 243 by the Australian Accounting Standards Board (AASB) (AASB 2013), which proposed the withdrawal of AASB 1031 Materiality in June 2013 (AASB 1995). AASB 1031 provided specific guidance on quantitative and qualitative materiality considerations. ED 243 proposed to replace AASB 1031 directions about materiality by including those discussions in AASB 108, an existing accounting standard (AASB 2015). The main reason for withdrawing the AABS 1031 Materiality Standard was to align the thinking about materiality with IASB (International Accounting Standards Board).

On 14 September 2017, the IASB issued a non-mandatory practice statement. Under the practice statement, firms can apply the materiality concept in preparing financial statements. The practice statement provided qualitative guidelines to determine the materiality 
of recognising, measuring, presenting, and disclosing financial Information in financial statements. The practice statement commented that financial Information is specific to firms and qualitative materiality judgements enhance the quality of materiality-led decisions (IFRS Foundation 2021a, 2021b). The AASB subsequently adopted the practice statement (AASB 2017).

The current AASB 108 has become the influencer of materiality judgements. A firm's policies, estimates, and errors can determine the nature and level of materiality. This standard provides principles-based guidance on materiality. Unlike AASB 1031, AASB 108 does not provide rule-based guidance to determine materiality qualitatively and quantitatively. The directions provided apply to a single item or a collection of items. The advice applies when the item is misstated or omitted. The AASB decided to withdraw AASB 1031 with the expectation that auditors' practice on materiality would continue, as in the past, under a rule-based approach (ED 243, paragraph BC7). However, no study has examined whether auditors' practice has continued to use a principle-based approach to materiality since the withdrawal of AASB 1031. This research gap links with financial information transparency, influencing firms accountability to shareholders and stakeholders who make financial information decisions. Materiality is a fundamental and vital accounting concept, but it is vulnerable to misuse (Messier et al. 2005). Applying the concept of materiality continues to be an ongoing challenge for regulators (Cameron 2014).

Section 2, which follows this introduction, examines the materiality concept from both Australian and international perspectives. Section 3 discusses authoritative standards guidance before and after the removal of AASB 1031, the accounting standard that dealt specifically with materiality. Section 4 considers the research undertaken on materiality using three research methods, and introduces research questions that deserve contemporary attention within this context.

\section{Materiality Concept}

Materiality has theoretical and practical implications in the accounting and auditing domains (Edgley 2014; Iskandar and Iselin 1999; Messier et al. 2005). We can classify perspectives on materiality as either international or Australian perspectives.

\subsection{International Perspectives}

- U.S. Supreme Court: A fact is material if there is "a substantial likelihood that a reasonable investor would have viewed the ... fact as having significantly altered the total mix of information made available" (U.S. Supreme Court 1976).

- U.S. Securities and Exchange Commission: “The term 'material', when used to qualify a requirement for the furnishing of Information as to any subject, limits the Information required to those matters about which an average prudent investor ought reasonably to be informed". Auditors must ensure in the Management Discussion and Analysis section of the financial reports that public firms provide sufficient Information about matters that have significant financial implications (Roberson 2005; SEC 2005).

- Financial Accounting Standards Board: "The omission or misstatement of an item is material in a financial report, if, in light of surrounding circumstances, the magnitude of the item is such that it is probable that the judgement of a reasonable person relying upon the report would have been changed or influenced by the inclusion or correction of an item" (FASB 1980; Siegel 1980).

- U.S. Auditing Standards Board: "Misstatements, including omissions, are considered to be material if they, individually or in the aggregate, could reasonably be expected to influence the economic decisions of users made based on the financial statements" (ASB 2019).

- International Federation of Accountants: “Omissions or misstatements of items are material if they could, individually or collectively, influence the economic decisions of users taken based on the financial statements. Materiality depends on the size and nature of the omission or misstatement judged in the surrounding circumstances. The 
size or nature of the item, or a combination of both, could be the determining factor" (IFAC 2009).

- International Accounting Standards Board: "Information becomes material if omitting it or misstating it could influence decisions users make based on financial Information about a specific reporting entity. In other words, materiality is an entity-specific aspect of relevance based on nature or magnitude, or both, of the items to which the Information relates in the context of an individual entity's financial report. Consequently, the Board cannot specify a uniform quantitative threshold for materiality or predetermine what could be material in a particular situation" (IFRS Foundation 2018). The definition was revised in 2018 as "Information is material if omitting, misstating or obscuring it could reasonably expect to influence decisions that the primary users of general-purpose financial statements make based on those financial statements, which provide financial information about a specific reporting entity" (IASB 2021).

- International Auditing and Assurance Standards Board: "Misstatements, including omissions, are considered material if they, individually or in the aggregate, could reasonably be expected to influence relevant decisions of intended users taken based on the subject matter information. The practitioner's consideration of materiality is a matter of professional judgement and is affected by the practitioner's perception of the common information needs of intended users as a group" (International Standard on Assurance Engagements-ISAE 3000) (IFAC 2011). "The auditor's determination of materiality is a matter or professional judgment, and is affected by the auditor's perception of the financial information needs of users of the financial statements. In this context, it is reasonable for the auditor to assume that users: have a reasonable knowledge of the business and economic activities and accounting and a willingness to study the Information in the financial statements with reasonable diligence; understand the financial statements are prepared, presented, and audited to levels of materiality; recognise the uncertainties inherent in the measurement of amounts based on the use of estimates, judgment and the considerations of future events; and make reasonable economic decisions on the basis of the Information in the financial statements. As explained in ISA 320, materiality and audit risk are considered when identifying and assessing the risks of material misstatement in classes of transactions, account balances and disclosures. The auditor's determination of materiality is a matter of professional judgment and is affected by the auditor's perception of the financial information needs of users of the financial statements (IAASB 2018). For the purpose of this International Standards on Auditing (ISA) and paragraph 18 of ISA 330, classes of transactions, account balances or disclosures are material if omitting, misstating or obscuring Information about them could reasonably be expected to influence the economic decisions of users taken on the basis of the financial statements as a whole" (ISA 315 Identifying and Assessing the Risks of Material Misstatement) (IAUSB 2019, 2020).

- International Integrated Reporting Council: The report "should disclose Information about matters that substantively affect the organisation's ability to create value over the short, medium and long term" (IIRC 2021).

- Centre for Corporate Governance: "Material information is any information which is reasonably capable of making a difference to the conclusions reasonable stakeholders may draw when reviewing the related information" (Centre for Corporate Governance 2016).

\subsection{Australian Perspectives}

- AASB 108 states that "Material omissions or misstatements of items are material if they could, individually or collectively, influence the economic decisions that users make based on the financial statements. Materiality depends on the size and nature of the omission or misstatement judged in the surrounding circumstances. The size or nature of the item, or a combination of both, could be the determining factor", as noted in paragraph five (AASB 2015). AASB 101 states that "Material omissions 
or misstatements of items are material if they could, individually or collectively, influence the economic decisions that users make based on the financial statements. Materiality depends on the size and nature of the omission or misstatement judged in the surrounding circumstances. The size or nature of the item, or a combination of both, could be the determining factor" (see paragraph seven). The AASB 108 contains the same definition as stated in paragraph five (AASB 2018). AASB Framework states that "Information is material if omitting it or misstating it could influence decisions users make based on financial Information about a specific reporting entity. In other words, materiality is an entity-specific aspect of relevance based on nature or magnitude, or both, of the items to which the Information relates in the context of an individual entity's financial report. Consequently, the Board cannot specify a uniform quantitative threshold for materiality or predetermine what could be material in a particular situation" (AASB 2016).

- Auditing and Assurance Standards Board: This is the materiality standard used in auditing to plan and perform an audit (paragraph two). "Misstatements, including omissions, are considered to be material if they, individually or in the aggregate, could reasonably be expected to influence the economic decisions of users taken based on the financial report; judgements about materiality are made in light of surrounding circumstances and are affected by the size or nature of a misstatement or a combination of both, and judgements about matters that are material to users of the financial report on the basis of the common financial information needs of users as a group. The possible effect of misstatements on specific individual users, whose needs may vary widely, is not considered" (AUASB 2015a).

These definitions of accounting materiality allow us to summarise common themes of materiality as follows: Firstly, the omissions or misstatements of items, transactions, balances, and events, individually or collectively, can influence those who use financial statements to make financially related decisions. Secondly, the surrounding situations can influence judgements about the contextual nature and magnitude of the omitted and misstated items. Thirdly, the contextual nature and magnitude of items investigated in the audit can influence the materiality judgement.

\section{Authoritative Standards and Guidance}

The Corporations Corporations Act (2001) provides the force of law to the accounting standards developed by the AASB (see section 334). Both the Corporations Act (section 336), and the ASIC (Australian Securities and Investment Commission) provide the force of law to the auditing standards created by the Assurance Standards Board (AUASB). Both sets of standards are legally enforceable within Australian jurisdictions.

\subsection{Materiality before Withdrawal of AABS 1031 Materiality Accounting Standard}

Before adopting IFRS in 2005, the AASB had its own specific standard for accounting materiality, AASB 1031 Materiality. The AASB 1031 Materiality concept regarding both nature and amount became applicable to all accounting standards in preparing and presenting financial reports. The objective of this materiality accounting standard was to define and explain the role of materiality in making judgements in preparing and presenting financial reports. This required the standards specified in other Australian Accounting Standards to be applied wherever Information resulting from their application was material. Paragraph 1 in AASB 1031 explains this.

Paragraph 9 of AASB 1031 stipulated that Information becomes material if its omission, misstatement, or non-disclosure has the potential-individually or collectively — to influence financial decisions made by people relying on firms' financial reports. These omissions and misstatements can influence managers and directors meeting their accountabilities. 


\subsection{Nature and Amount in Materiality Judgement}

Judging that an item is material requires examining the item individually and in aggregation. The judgement includes looking at both nature and amount. However, in particular circumstances, either the nature or amount of an item individually or of an aggregate of items independent of each other could determine materiality. This is illustrated in paragraphs 12 (a) and 12 (b) (i)-(iv) in AASB 1031:

I. The amount alone is the determinant for error corrections.

II. The amount determines the adjustments relating to events occurring after the balance date requiring adjustments.

III. The nature of the item determines materiality about transactions occurring between an entity and parties who have a fiduciary responsibility about that entity. The Accounting Standard AASB 124 Related Party Disclosures outlines those events and transactions.

IV. The nature of the item determines the restrictions on the entity's powers and operations that affect the risks and uncertainties. An example is laws imposed by governments on assets held in foreign countries.

V. The nature of the item determined can change when an entity expands its operations into a new segment affecting risks and opportunities facing the entity.

VI. The nature of the item determines where the entity is in danger of breaching a financial covenant.

\subsection{Other Quantitative and Qualitative Factors}

The following quantitative thresholds (paragraph 15 of AASB1031) provided guidance in considering the materiality of an item in the absence of evidence, or convincing argument, to the contrary:

I. An amount equal to or less than 5 per cent of the appropriate base amount is presumed not to be material.

II. An amount equal to or greater than 10 per cent of the proper base amount is presumed to be material.

III. An amount greater than 5 per cent but less than 10 per cent is known as the "grey area". Other factors such as the accounting treatment of different items in the same class of transactions or balances may establish treatment for financial statements.

IV. Other qualitative factors (paragraphs 17 and18 of AASB 1031) were applicable under AASB 1031. These include:

V. Financial restrictions under debenture deeds, debt convents or fiduciary duties of managers can make items less material than quantitatively indicated above.

VI. Changes in regular activities can turn a profit into a loss or create a margin of solvency in a balance sheet. These actions can focus on the materiality of revenue and expense items to the change in profit or asset revaluations that can reverse the solvency or net asset position.

\subsection{After Withdrawal of the Materiality Accounting Standard in Australia}

Figure 1 provides a timeline for the application of the materiality concept in accounting. In September 2020, the IASB updated its Information about materiality through a revised Conceptual Framework on Financial Reporting as shown in paragraph BC3 of Exposure Draft (ED) 243 published in 2013 by publishing the IFRS Practice Statement 2 (IASB 2021). In 2013, the AASB decided to withdraw AASB 1031 to achieve consistency with its policy on matters covered by paragraph BC5 of ED 243. 


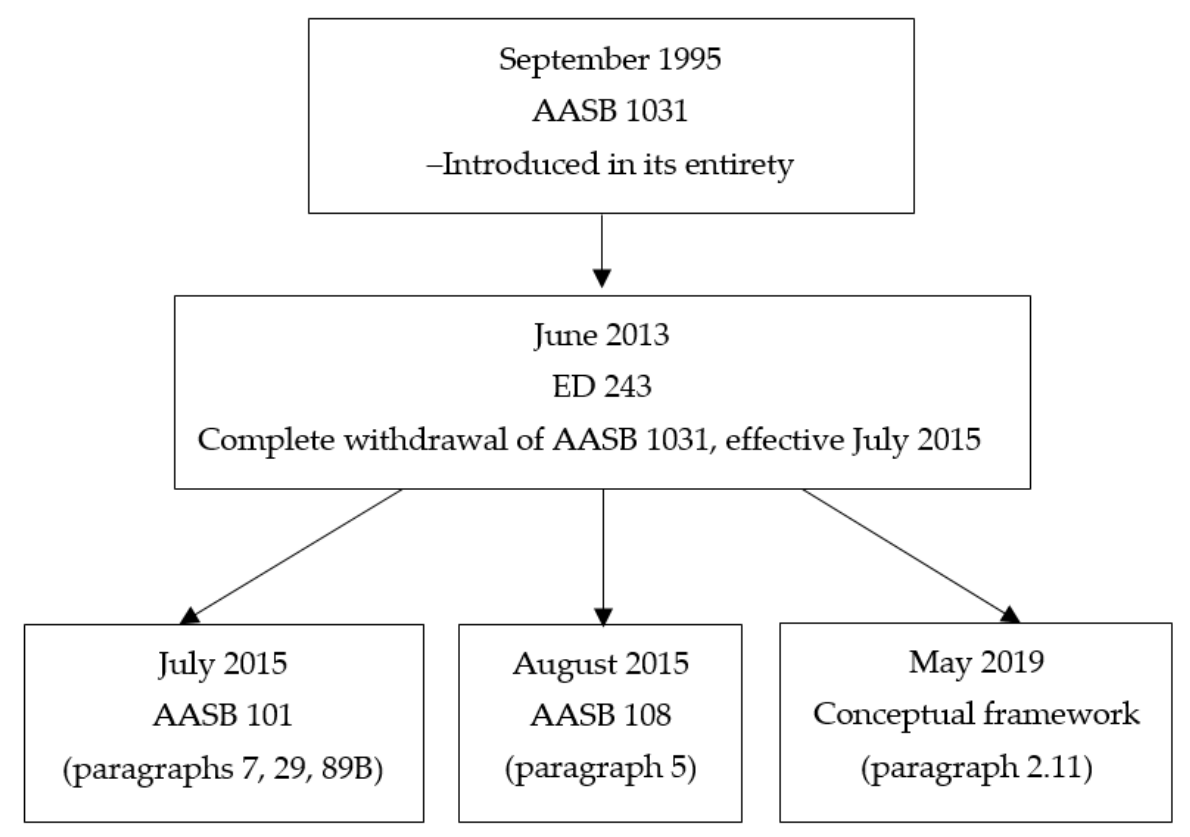

Figure 1. Evolution of the Materiality Concept and application in Australia.

The Exposure Draft proposed withdrawing AASB 1031; the AASB noted that withdrawal would change the practice regarding applying materiality in financial reporting (paragraph BC7 of ED 243). This constitutes the predominant research gap and primary motivation for conducting the current research and subsequent recommended research. To date, there has been minimal empirical research on auditors' materiality judgements after the withdrawal of the specific Australian materiality standard.

As of 1 July 2015, AASB 1031, AASB 108 (paragraph 7), and AASB 101 (paragraph 5) contain exactly the same definition of materiality as that used in the IFRS. Thus, the only limited guidance available on materiality and its meaning is as follows:

"Material omissions or misstatements of items are material if they could, individually or collectively, influence the economic decisions that users make based on the financial statements. Materiality depends on the size and nature of the omission or misstatement judged in the surrounding circumstances. The size or nature of the item, or a combination of both, could be the determining factor in planning and performing an audit" (РCAOB 2021).

The Conceptual Framework of Accounting (paragraph QC11 of ED 243) states that omissions or misstatements of Information become material only if those using financial reports are influenced by them in making financial decisions.

The new AASB 101 and AASB 108 positions contrast with the previously established quantitative materiality factors of AASB 1031 Materiality. An important empirical question is whether the withdrawal of the AASB 1031 Materiality standard has led to auditors having a uniform decision-making basis for making materiality assessments using principle-based judgements.

\subsection{Role of Materiality in the Audit Process}

Materiality is a crucial concept for users of financial statements, regulators, and auditors (Eilifsen and Messier 2015). The auditor must first receive the Information, then judge whether Information is material as it appears in financial reports (Eilifsen and Messier 2015). Several relevant accounting and auditing standards become applicable for the auditor to ascertain the materiality of Information in conducting the audit.

As shown in Figure 2, on the accounting side, these standards include the Conceptual Framework (AASB 2016), AASB 101 (AASB 2018), and AASB 108 (AASB 2015). The Con- 
ceptual Framework provides the founding concepts dealt with in the accounting standard. AASB 101 explains the presentation of material information in financial statements, while AASB 108 explains the policies, the process of making changes to accounting estimates, and the process of dealing with errors that can significantly influence financial decisions. ASA 240 (AUASB 2006), ASA 315 (AUASB 2015a), ASA 320 (AUASB 2015b), and ASA 450 (AUASB 2015c) relate to the auditing arena. ASA 240 differentiates fraud from errors, and requires auditors to consider material misstatements due to occurrences of fraud mandatorily. These misstatements can arise from misappropriating assets and misstating Information that leads to fraudulent financial reporting. The auditor must evaluate controls in place and their implementation, establish documents, need managements written representations about them, and communicate them with those who take leadership in governance. ASA 315 relates to the development of an understanding of the enterprise environment in which the firm being audited operates in order to identify and assess risks. The level of risk influences the level at which the materiality standard is set. ASA 320 applies in conducting the audit; in the current setting, auditors must qualitatively judge what Information is material by considering the amount and nature of the financial effects resulting from that Information. ASA 450 provides guidance for evaluating misstated items that have been identified.

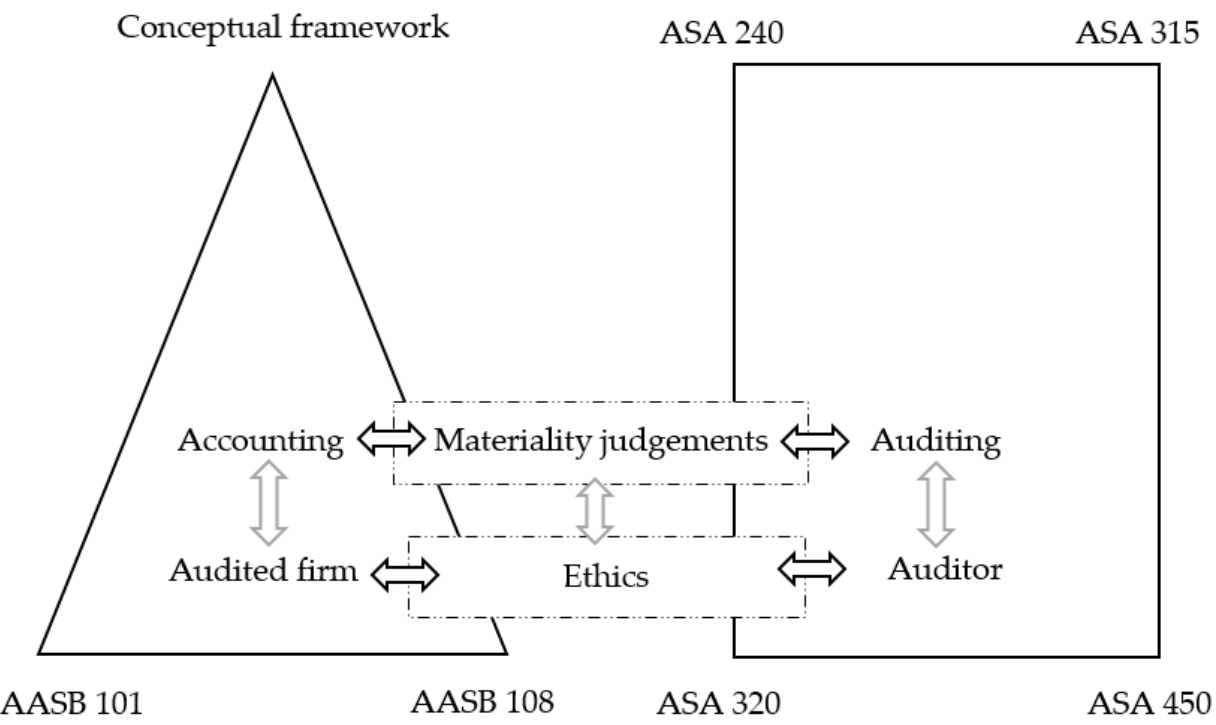

Figure 2. Interconnection between accounting and auditing pronouncements about materiality judgements.

The concept of materiality discussed in these accounting and auditing pronouncements play a central role in three aspects. First, it determines the sampling undertaken for audits. Second, it influences the tolerable error level as materiality for individual itemsindividual materiality level) and items aggregated for such assessments-aggregated materiality level. Third, it assists in making conclusions about reasonable rather than absolute audit assurance to balance against the cost of conducting an audit and making informed judgements about financial reports (Houghton et al. 2011).

Auditors must have sufficient financial knowledge in designing, performing, and making ethical judgements about the materiality of financial Information, so that the audited financial reports provide reasonable assurance that there are no material omissions or misstatements. The goal of conducting an audit with an underpinning materiality concept is not to catch every misstatement (Eilifsen and Messier 2015; Kristensen 2015). The materiality concept assists auditors to assess materiality for the financial statements as a whole. Consequently, auditors design and conduct an audit to examine accounts and disclosures where there is a risk of omitted or misstated Information (Kristensen 2015). 


\section{Background Literature Informing Research Questions}

The most crucial indicator used to assess the materiality of Information is the percentage effect on profit before tax (PBT). Holstrum and Messier (1982) remarked that the absence of guidelines could explain the variance among auditors; since individual auditors judge materiality, their judgements can differ. The diversity between various judgements based on professional norms stands in contrast to the rule-based judgements previously being issued. Messier et al. (2005) also find that authoritative guidance can influence an auditor's materiality judgement. Iskandar and Iselin (1999) and Messier et al. (2005) suggest that the auditor's specific characteristics—especially experience-are essential, and that audit firm structure has a significant influence on the judgement made. A common misunderstanding is that auditing is a heuristic process (Joyce and Libby 1982; Stringer 1981). It has now become a process where auditors make firm-specific judgements (Dirsmith and McAllister 1982; Smith et al. 2001; Sullivan 1984).

The previous reviews of materiality contain contradictions: on the one hand, researchers describe percentage effect on net income or profit before tax (PBT) as the most crucial factor - that is, a quantitative measure and a practical rule of thumb (heuristics). On the other hand, they suggest that significant differences between and among groups exist, which should not be possible if a single measure determines the materiality threshold (Kristensen 2015). These differences between and among groups support the assumption that assessment of materiality is not just a task (audit engagement) but also includes the auditor's personal attributes and auditor interactions (Nelson and Tan 2005).

\subsection{Materiality Research Using Survey Questionnaires}

Since 1950, the concept of materiality has come under study. The quantitative orientation towards materiality determination may have influenced researchers to examine the validity of quantitative measurement of materiality (Iskandar and Iselin 1999). The first empirical materiality research was conducted by Woolsey (1954) — an analysis done using a questionnaire. Woolsey measured materiality using profit before income taxes in relation to revenue. The heuristic followed was the indicator that less than five per cent was not considered material, while more than 15 per cent was considered material (Iskandar and Iselin 1999; Woolsey 1954). Ward (1976) conducted another significant materiality study using a survey. This research found that auditors could not reach uniform agreement in judging materiality. That is, no two auditors' judgements are alike (Ward 1976). Eilifsen and Messier (2015) examined materiality heuristically, finding a materiality indicator of above 10 per cent, with profit before income taxes over revenue as a benchmark.

There was substantial agreement on determining performance materiality (also known as tolerable error), with most firms using a 50 to 75 per cent range. There was also agreement on what constitutes a trivial misstatement: three to five per cent of overall materiality (Eilifsen and Messier 2015). These studies showed that auditors use heuristics, also known as "rule of thumb". These findings exposed an essential research gap, raising two questions:

I. Are these heuristics of quantitative calculations of audit materiality still prevalent after the withdrawal of the AASB 1031 Materiality Standard?

II. How do auditors evaluate misstatements that have been identified but not corrected, incorporating any qualitative factors influencing materiality assessments?

\subsection{Materiality Research Using Archival Studies}

Neumann (1968) introduced archival studies of materiality. Studying a sample of auditors' reports to investigate the concept of materiality, his main findings were that qualified opinions showed materiality within the grey area: not material below five per cent and material above 10 per cent of net income (Neumann 1968). Frishkoff (1970), on the other hand, using the same archival methods, commented that the dividing line between qualified and unqualified audit reports was on average 25 per cent. Several archival studies reconfirmed that, in terms of quantitative factors of materiality, the percentage effect on net 
income was the most researched quantitative measure, with earnings trend or total assets coming a distant second. At the same time, most of these archival studies found that a five to 10 per cent effect on profit before tax was the most popular materiality heuristic, reflecting relevant accounting standards and guidance during the periods in question (Acito et al. 2009; Chewning et al. 1998; Steinbart 1987).

Client-specific situational factors can influence auditors' assessment processes and judgements about materiality. An increased risk of impact from Information being omitted and misstated can increase the materiality level that is set. Certain situations such as industry membership and firm governance structure can also increase the variability in evaluating Information for materiality (inherent risk) (Blokdijk et al. 2003; Keune and Johnstone 2009; Steinbart 1987), whereas an increase in the quality of the client's control environment (control risk) should trigger an increase in materiality thresholds (Blokdijk et al. 2003). Chewning et al. (1989) added that the materiality level decreases with an item's level of subjectivity under the audit. These archival materiality studies also revealed the impact of clients' wish to meet earnings thresholds-whether a firm meets its earnings threshold through beneficial earnings management, making prudent accruals using insider firm knowledge to the benefit of financial report users, or through pernicious earnings management accruals made to benefit managers achieving their performance targets rather than assisting financial report users with making accurate financial decisions. The two situations can trigger auditors to set different risk levels and materiality levels (Keune and Johnstone 2012). As Kristensen (2015) state, making materiality assessments is complex. The older literature show that non-Big-4 audit partners set lower materiality levels than Big-4 partners (Chewning et al. 1989). However, Blokdijk et al. (2003) and Keune and Johnstone (2009) found the opposite. These contradictory findings points out that materiality judgements are influenced by auditor firm, and subjected to change over time.

A study analysed audit reports submitted to the Public Company Accounting Oversight Board (PCAOB) as part of the audit inspection procedure. The study used the materiality dollar amount that the audit firm has reported to PCAOB. They found that auditors do not follow the conventional 5 per cent on profits before income taxes as a dollar amount as a tolerable level rule of thumb to determine the materiality of items. Instead, the firm income, revenue, and assets influence this determination. In addition, the auditors manual and enterprise characteristics also influence the materiality level set. The most common materiality basses were before income taxes used by 60 per cent, revenue used by 17 per cent, net income used by 8 per cent, and assets used by 4.5 per cent. In addition, the audit hours and audit fees closely associated with audit adjustments proposed to the firm as correcting misstatements, although materiality is not the sole determinant of audit fees (Choudhary et al. 2019).

Firms identify accounting errors through internal control procedures of internal audits and external audits conducted. Materiality judgements assist in determining which errors to correct and how to inform users. Prior period material errors in financial statements require corrections. However, non-material previous period errors do not require adjustments, corrected informally in the current period, or restored as an adjustment in the current period to catch up with the prior period. The firm disclosure in the U.S. is more prominent when adjustment is a catching-up or revision than a restatement. The firm must complete a form that includes a narrative explanation and file with the Securities Exchange Commission (SEC), Information available to the public. SEC issued Staff Accounting Bulletin (SAB) Number 99 to guide firms on an illustrative list of items below the quantitative threshold but adjudged as materiality items (SEC 1999). Managers use multiple benchmarks to analyse the materiality of Information for financial reporting; the most common is 5 per cent profits before taxes. A study found that between 17 and 26 per cent of cases where the item considered exceeded the quantitative benchmark, managers justified them as not material using qualitative factors, are suspicious material cases. However, SEC has not formally investigated, as SEC is usually respectful of managerial judgements. Instead, 
SEC is bound to challenge managers to state items as material due to qualitative factors (Acito et al. 2019).

\subsection{Materiality Research Using Experimental Studies}

Iskandar and Iselin (1999) literature review found that researchers are increasingly using experiments to determine materiality levels. The experiments allow them to examine causal factors in complex situations by controlling for confounding variables (Iskandar and Iselin 1999). The experimental approach is the predominant research method used for materiality studies since 1974, as initiated by Boatman and Robertson. They used an experimental design to study 18 CPAs (all of which were audit partners) and 15 securities analysts, to make judgements on disclosure of items, and recommended an effect of greater than four per cent benchmark against net income (Boatsman and Robertson 1974). Seventyfour per cent of the CPAs concluded these are immaterial (i.e., four per cent rule). In comparison, only 35 per cent of securities analysts resolved that these are immaterial disclosures, thereby implying that securities analysts were more conservative than auditors when it came to materiality assessment.

Archival studies (Blokdijk et al. 2003; Keune and Johnstone 2009; Steinbart 1987) contributed to materiality research by showing that firm-specific factors can influence auditor judgement about materiality. In contrast, the experimental studies conducted by Krogstad et al. (1984) and Mayper et al. (1989) found that an increase in the quality of a client's control environment should trigger an increase in materiality thresholds. Materiality studies that utilise the experiment-based approach. $\mathrm{Ng}$ (2007) showed that a client's wish to meet earnings thresholds affected the auditors decision to book or waive audit differences. These affect the materiality level. Ng's experimental study found the same results as Keune and Johnstone (2012), who examined materiality using archives. Auditors' perception of management and the presence of other identified accounting errors also affect materiality levels (Arnold et al. 2001; DeZoort et al. 2003; Wang-On-Wing et al. 1989).

Another part of the audit task is related to items under audit. The significant finding here is that auditors use lower materiality levels when the item under audit is subjective (e.g., accounting estimates) or a non-routine transaction. An archival study found that the materiality level decreases with the subjectivity of the item (Chewning et al. 1989). However, newer experimental studies reported the opposite (Nelson et al. 2005; Ng 2007). Not only the firm's situational factors but also auditor factors influence materiality levels. When the auditor has developed capability with more experience, the perceived risk can differ from a junior auditor because of greater detection and better judgement skills of the experienced auditor (Kristensen 2015).

Previous experiment-based research reports that auditors set higher materiality levels when conducting fewer complex audits (Messier 1983). Carpenter and Dirsmith (1992) found that experienced auditors are comfortable setting lower materiality levels. This is very much the case with unstructured and incomplete Information, in making judgements about its influence on financial decision-making (Carpenter and Dirsmith 1992). These findings indicate that an auditor can better assess the nature of an item under audit and assess the materiality of the item with experience. By contrast, higher risk or more uncertainty results in a lower materiality level than that found in the previous archival study conducted by Steinbart (1987). Surprisingly, prior research regarding consensus among auditors shows that no two auditors are alike-i.e., they have different individual decision models (Moriarity and Barron 1976, 1979). Moreover, there is a lack of consensus regarding materiality within the auditing profession (Firth 1979; Jennings et al. 1987; Mayper 1982). Kristensen (2015) indicated that two factors contribute to the lack of auditor agreement. First is the difficulty of formulating an exact set of rules for materiality assessments. The second is performing materiality assessments with the same minimum quality level.

Experimental studies regarding interactions between stakeholders and auditors when making materiality decisions are minimal. Jennings et al. (1987) found a lack of consensus among auditors and financial statement users. This is contrary to the findings in Boatsman 
and Robertson (1974) older study, which reported that the judgement processes of auditors and financial statement users do not differ in any significant respect. This contradiction could be related to the time periods during which the studies took place. They could also reflect differing validity of the studies (Kristensen 2015).

Most studies favour official materiality guidance. They find that this reduces the variability in auditors' materiality assessments, making them more equal (DeZoort et al. 2003; Firth 1979), which seems contrary to the decision made by the AASB to withdraw AASB 1031.

\subsection{Research Gaps in the Literature}

Because the mandating heuristics guidelines for materiality judgements have now been removed, it is unclear which details should affect auditors' materiality judgements. The introduction of a qualitative approach to materiality makes materiality into a checkbox to fill in with a priori judgment (Nelson and Tan 2005). The needs of users have also changed, because previously only shareholders relied on financial reports, but now other stakeholders also rely on this Information to make financial decisions (Kristensen 2015). Some research points out that the Big- 4 audit firms' audit manuals prescribe heuristics that perpetuate quantitative judgements (Eilifsen and Messier 2015). The non-Big Four audit firms also use heuristics, but in different ways. Some researchers suggest the audit judgement differences are due to differences in heuristic outcomes rather qualitative approaches (Edgley 2014; Holstrum and Messier 1982; Kristensen 2015; Martinov-Bennie and Roebuck 1998; Messier et al. 2005; Patterson and Smith 2003). As with overall approaches to financial accounting and auditing, the standard setters promulgate principle-based judgements (Acito et al. 2009).

The qualitative approach to materiality assessment is less documented in research because of a lack of evidence as to how auditors make materiality judgements (Bernstein 1967; Edgley 2014; Kristensen 2015). The established knowledge leads to a central research question: How do auditors assess materiality misstatements in the financial statements after the withdrawal of AASB 1031?

This review is restricted to a discussion of financial auditing, based on articles published in English language. There may be articles published in other languages that are relevant to the materiality discussion. Materiality is also an important determinant in non-financial accounting arenas such as social and environmental accounting. For example, water accounting follows the same materiality concept as in financial accounting (WASB 2012). One significant difference is that financial accounting has more structured data to audit, whereas non-financial audits work with more unstructured data. This paper acknowledges such differences in the nature of data and proposes a framework to generate research questions as shown in Figure 2.

As shown in Figure 3, for the purpose of this study, the central research theme of materiality sits in a tripartite arrangement: (I) ethics, the auditor conducting (II) the auditor, and (III) the audited firm.

(I) Ethics - the first essential element-is a multidimensional construct with five dimensions. The first is that the auditor is honest and unambiguous in conducting the relationships (integrity). The second is that the auditor does not allow others to influence audit decisions. The auditor relies only on the competencies gained through formal training and validated experience (objectivity). Third, the auditor is up to date with current knowledge and experience, and has met required competencies to design, perform, and complete the audit (professional competence and due care). Fourth is that the auditor in the course of the audit has access to firm Information but keeps it confidential and secure. The auditor does not share it with others and uses it for the purpose of audit only, unless the law of the country requires disclosure (confidentiality). Fifth is that the auditor follows and complies with laws and regulations expected of a responsible citizen, behaves in a manner that does not reflect badly on the auditor, the employer the auditor represents, or the accounting profession (professional behaviour) (CAANZ 2021). 
(II) Auditor-the second essential element of materiality research is the auditor conducting the audit. This study follows the auditor construct developed by the Australian Securities and Investment Commission (ASIC) in Australia. This refers to an auditor who has followed Regulatory Guide 180 Auditor Registration and is registered under ASIC.

There are four dimensions to the auditor construct: (i) qualifications; (ii) skills; (iii) capability, and (iv) fit. To satisfy the qualifications dimension, the auditor has qualifications prescribed or equivalent to those prescribed by ASIC. The prescribed qualification requires three years of accounting study, two years of commercial law study, a prescribed course of study in auditing, and a qualification obtained from a list of institutions prescribed by ASIC. An alternative route is an equivalent qualification. This route requires an auditor to satisfy in writing a statement and obtain ASIC approval that alternative qualifications and experience meet the prescribed requirement (section 1280 [2A]). The second dimension is skills. There are three routes to meeting the skills requirement. The first is that the person has achieved the required skills through three to five years of continuous assessment (auditor competency standard). The second is that the person has completed $3000 \mathrm{~h}$ of audit experience under a registered auditor immediately before auditor registration. This includes completing $750 \mathrm{~h}$ of supervising audit (prescribed practical experience). If the person cannot meet these two requirements, they must show the ASIC they can satisfy the auditor competency standard or prescribed practical experience, which generally includes having 12 months' relevant practical experience in Australia. The third dimension is being a person capable of acting as auditor. The capability report must show that the auditor can conduct complex audits by referring to the three most important audits they have conducted, and continuing professional development undertaken in the past five years. The fourth dimension is that the person meets the fit and proper person status to conduct an audit as required by ASIC. The fit and proper person status is determined by qualifications, disciplinary actions, litigation matters relating to the person, previous applications, removal of registration, and whether the person is under administration (ASIC 2021).

(III) Audited firm - the third basic construct within materiality research is the firm. A firm is an entity that requires a financial audit of their affairs. This can include a company, a business name, a registered name, a foreign company, an association, a managed investment fund, or a firm that is not registered. These entities must have a name and a unique identifier number such as ABN (Australian Business Number, ACN (Australian Company Number), ARBN (Australian Registered Business Number), or ARSN (Australian Registered Superannuation Number) (ASIC 2021).

The Australian Securities and Investment Commission (ASIC) is responsible for registering company auditors. The Regulatory Guide 180 (RG 180) provides details of the process and requirements. The assessor must consider an auditor applicant's professional values, ethics, and attitudes: commitment to the public interest, professional skepticism, professional judgement, and ethical principles (CPAA CAANZ IPA 2015). The firm's culture can have a substantial effect on its values, ethics, and attitudes. The corporate collapse of Enron highlights the role of corporate culture in these (Sims and Brinkmann 2003). Greater compatibility between firms and auditors on values, ethics, and attitudes can facilitate more uniform qualitative materiality judgements. 


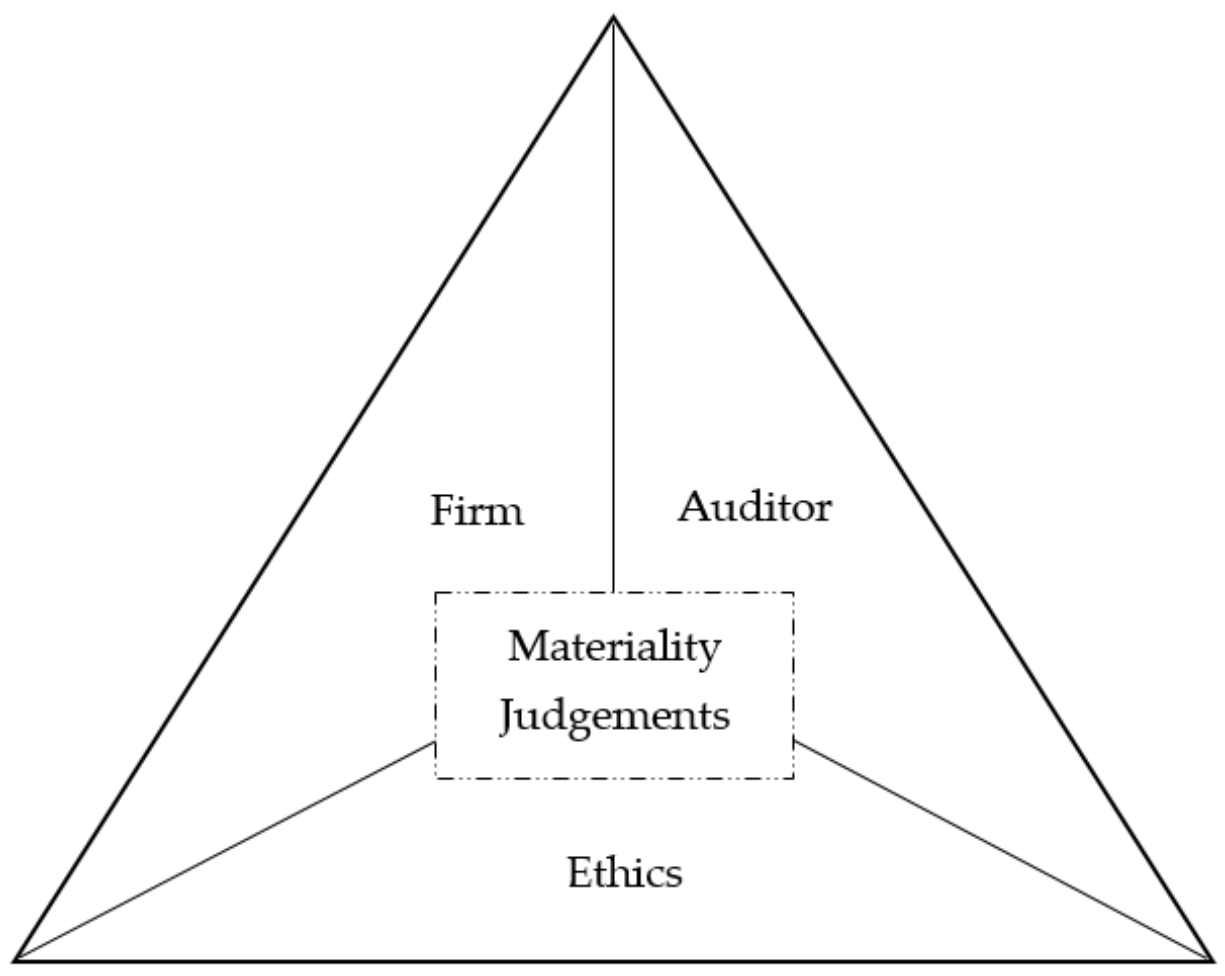

Figure 3. An audit triangle for materiality research.

Auditors can get into trouble in two ways: ethics complaints and the peer-review process. An auditor must make a conscious decision to leave clients that are not serviceable in terms of proficiency and professionalism (Nogler and Armstrong 2013). The auditor must consider a firm's characteristics, including size, industry membership, and staffing profiles, and set materiality levels for events and transactions investigated within that framework (Iselin and Iskandar 2003). The auditor must also judge the relevance and benefit to investors of material information until the accounting profession has recommended a comprehensive approach to disclosure requirements (SEC 2013). The interplay between firm and auditor can substantially influence audit quality, and materiality judgement plays a vital role.

This paper identifies the following research questions based on this tripartite arrangement. I. Ethics

1. To what extent do enterprise values systems influence materiality risk?

2. To what extent do the CEO's ethical standards influence materiality risk?

3. Is there a relationship between the ethical wrongdoings of an enterprise and materiality risk?

4. How ethical are audit firms conducting audits of the enterprise in determining materiality risk?

5. Is there a relationship between auditor rotation cycle, audit partner duration of an audit, and setting materiality risks?

II. Auditor

1. How does an experienced auditor (fully competent-working with no supervision) differ from an inexperienced auditor (less than fully competentworking under supervision) in making materiality decisions?

2. How do auditors assess materiality at different stages of an audit-planning stage, performance stage, and audit completion stage?

3. How does an auditor identify tolerable errors and clearly trivial errors?

4. How does an auditor evaluate misstatements at different stages (planning, performance, and completion) of the audit? 
5. How does an auditor evaluate omissions at different stages (planning, performance, and completion) of the audit?

III. Audited Firm

1. What are the key commonly-agreed indicators an auditor considers with respect to the risk level of Information?

2. How does the CEO's personality contribute to the materiality risks of an audit?

3. To what extent does the group structure (a parent firm, subsidiary firm, associate firm, joint venture firm, investing firm) influence the materiality risk of an audit?

4. To what extent does the overseas exposure of the firm (trading relationships, physical presence in another geographic area) influence the materiality risk of an audit?

5. To what extent can an investing relationship in another geographic area influence the materiality risk of an audit?

IV. Auditor-Ethics-Firm Triangle These are research questions pertaining to entire triangle:

1. Do the auditor's personal ethical standards moderate firm-level ethics in determining materiality judgements?

2. To what extent can auditor dependence on the firm influence the application of ethics to materiality judgements?

3. Do the frequency, duration, and currency of continuous professional development influence materiality judgements?

4. Are there significant differences in materiality judgements between auditors completing the prescribed registration route versus alternative registration routes?

5. To what extent does having an audit committee in firms moderate auditor materiality judgements?

This paper has identified 20 questions for future research, with specific reference to each element in the tripartite arrangement. It has also examined the intersection of the three points in the triad to bring forth more holistic research questions. The article points out that finding evidence-based solutions to these types of questions can enrich the qualitative paradigm of materiality judgements, which is here to stay under the principlebased accounting and auditing approach embraced across the world. As pointed out in this article, materiality is a construct arising from the interaction of three elements: auditor, firm, and ethics. Materiality is also an essential determinant of audit quality, where an auditor follows auditing standards in the audit of a financial report or financial review (section 307 A Corporations Act) (ASIC 2021). The qualitative approach to materiality auditing takes on increasing importance in the contemporary enterprise environment, where there is a significant increase in the nature and volume of unstructured data. The risk inherent in data increases proportionately with the risk that management can take control over otherwise structurally arranged data and Information through policies and internal control procedures (Bellandi 2018, pp. 347-61). Auditors duly communicating their duties and responsibilities that examined these data leading to financial reports can decrease the audit expectation gap (Monroe and Woodliff 1993) - harmonising the public beliefs of messages conveyed through audit reports and actual audit work conducted. These data require verification for accuracy and completeness in order to be of benefit to users, ethical, and values-driven (Nicholls 2018); this can allow auditors to take comfort that Information in financial reports presents a true and fair view.

This paper conceptualised audited firm as those entities with a name and unique identifier number. Public sector institutions do not fall within that concept but are a sector that requires an audited financial report. Supreme Audit Institutions (SAI) fill that vacuum created under national legislations. Countries have different names for SAI. The 
Napoleonic system SAI has combined judicial and administrative authority and integrates with the laws for their compliance. The European and Latin American countries follow this system. The Westminister System SAI found with Commonwealth countries has an Auditor General directly reporting to the Parliament. The Commonwealth countries follow this system. The Auditor-General office has a collection of experts conducting audits of operations and financial reports of public sector entities. The Board System found in Asian countries has an audit board comprising two arms-an audit commission to make decisions and a general executive bureau to execute these decisions. The Board aims to analyse government revenue and expenditure and report to the Parliament (Stapenhurst and Titsworth 1991). The SAI members of an umbrella body-International Organisation of Supreme Audit Institutions (INTOSAI) - share international standards and best practices for public sector auditing. INTOSAI offer full membership to SAI of countries that are members of the United Nations Organisation or its specialised agencies. It also provides full membership to SAI of supranational organisations that must follow international laws, legal status and sufficient technical, economic, or financial integration. Currently, there are 195 full members (INTOSAI 2021).

Unlike the private auditors, SAI and INTOSAI have more influence on shaping public policy and public-management reform (Pierre and de Fine Licht 2019). Public sector auditing is more value for money than mere financials and compliance with accounting standards. They are focused on efficiencies, effectiveness, and economies of resources and reaching intended objectives. There is increasing consensus among the SAI community to extend the value for money audit towards sustainability in auditing for financials, compliance, and performance (Bringselius 2018; Smith et al. 2021).

As shown in Figure 4, the public sector audits can adopt the concept of triple bottom line reporting (Elkington 1997) as responding to the expanded scope of activities undertaken as value for money. Then auditing can respond to the sustainability value for money based on such reporting. The public sector firms continue to deploy their resources with value for money, and their governance plays a vital role. Inculcating a code of ethics accompanied with implications for deviations is crucial to increase value for money performance now and in the future.

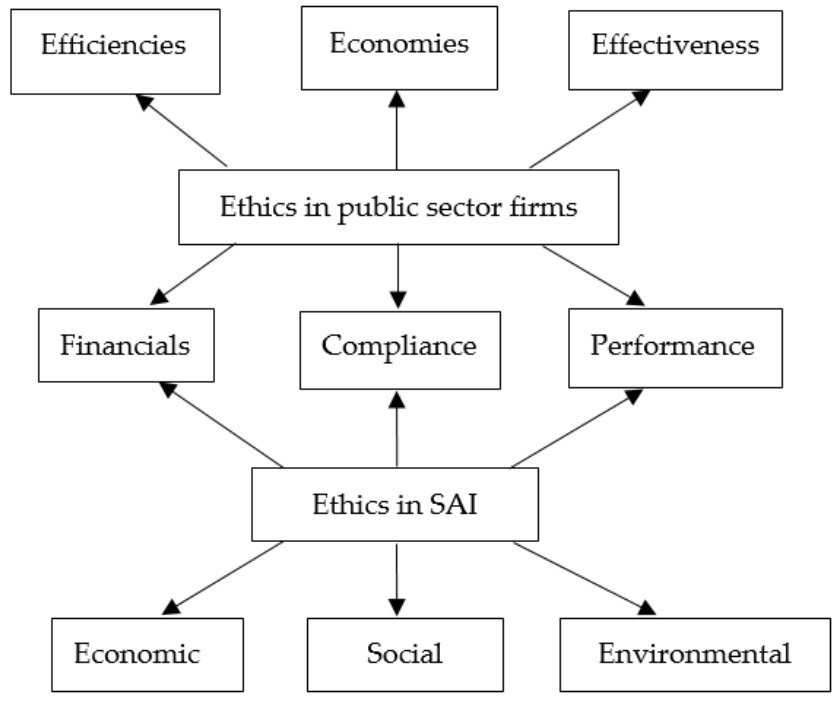

Figure 4. Expanding value for money audits in the public sector.

The code of public sector firms audits must pervade into their financials, compliances, and performances. SAI can play a vital role in upholding the ethics of public sector firms, making them accountable for actions and making those actions as far as possible transparent to stakeholders (Dye and Stapenhur 1998). The INTOSAI code of ethics requires SAI to follow five ethical values: 1 . Integrity, 2. Independence and Objectivity, 3. Competence, 
4. Professional Behaviour, and 5. Confidentiality and Transparency (INTOSAI Journal 2021). These are similar to the standards of ethical conduct applicable to professionally qualified accountants bringing alignment of ethical expectations between SAI and professional accountants (CAANZ 2021). The public sector firms with expanded reporting frameworks have begun to adopt sustainability reporting with an internal stakeholder focus (Farneti and Guthrie 2009). The focus must expand to include internal and external stakeholders. Auditors can avail of the Global Reporting Initiative (GRI) framework (GRI 2021) and United Nations 17 Sustainability Development Goals framework (UNDP 2021). The time has arrived for all firms to expand their compliance, performance, and reporting frameworks. All auditors and audited firms by and large to expand the sphere of mainstream audits have opened up many future research propositions.

Author Contributions: R.D. wrote the first internal draft; I.A. reviewed and revised the manuscript (from the first submission to final acceptance by the journal). R.D. is a higher degree research student under principal supervision of I.A. Both authors have read and agreed to the published version of the manuscript.

Funding: This review received no external funding.

Conflicts of Interest: The authors declare no conflict of interest.

\section{References}

AASB. 1995. Accounting Standard AASB 1031 Materiality. Australian Accounting Standards Board (AASB). Available online: https:/ / www.aasb.gov.au/admin/file/content102/c3/AASB1031_9-95.pdf (accessed on 31 May 2021).

AASB. 2013. ED243 Withdrawal of AASB 1031 Materiality. Australian Accounting Standards Board. Australian Government. Available online: https:/ / www.aasb.gov.au/admin/file/content105/c9/ACCED243_06-13.pdf (accessed on 31 May 2021).

AASB. 2015. Accounting Standard AASB 108 Accounting Policies, Changes in Accounting Estimates and Errors. In Australian Accounting Standards Board. Australian Government. Available online: https://www.aasb.gov.au/admin/file/content105/c9 /AASB108_08-15.pdf (accessed on 31 May 2021).

AASB. 2016. Framework for the Preparation and Presentation of Financial Statements. In Australian Accounting Standards Board. Australian Government. Available online: https://www.auasb.gov.au/admin/file/content102/c3/Framework_07-04nd.pdf (accessed on 31 May 2021).

AASB. 2017. Making Materiality Judgements. Complied AASB Practice Statement. AASB Practice Statement 2. Australian Accounting Standards Board. Australian Government. Available online: https://www.aasb.gov.au/admin/file/content102/c3/AASBPS2_1 2-17.pdf (accessed on 24 April 2021).

AASB. 2018. Accounting Standard AASB 101 Presentation of Financial Statements. Australian Accounting Standards Board. Australian Government. Available online: https://www.aasb.gov.au/admin/file/content105/c9/AASB101_07-15.pdf (accessed on 31 May 2021).

Acito, Andrew A., Jeffrey J. Burks, and W. Bruce Johnson. 2009. Materiality Decisions and the Correction of Accounting Errors. The Accounting Review 84: 659-88. [CrossRef]

Acito, Andrew, Jeffrey J. Burks, and W. Bruce Johnson. 2019. The Materiality of Accounting Errors: Evidence from SEC Common Letters. Contemporary Accounting Research 36: 839-68. [CrossRef]

Arnold, Donald F., Sr., Richard A. Bernardi, and Presha E. Neidermeyer. 2001. The Association between European Materiality Estimates and Client Integrity, National Culture, and Litigation. The International Journal of Accountancy 36: 459-83. [CrossRef]

ASB (Auditing Standards Board). 2019. Statement on Auditing Standards 138. Statement on Auditing Standards Amendment to the Description of the Concept of Materiality. Available online: https:/ /www.aicpa.org/content/dam/aicpa/research/standards/ auditattest/downloadabledocuments/sas-138.pdf (accessed on 31 May 2021).

ASIC (Australian Securities and Investment Commission). 2021. Company Auditors. Available online: https://asic.gov.au/for-financeprofessionals/company-auditors / (accessed on 20 May 2021).

AUASB (Auditing and Assurance Standards Board). 2006. Auditing Standard ASA240. The Auditor's Responsibility to Consider Fraud in an Audit of a Financial Report. Available online: https:/ /www.legislation.gov.au/Details/F2006L01368 (accessed on 6 June 2021).

AUASB (Auditing and Assurance Standards Board). 2015a. Auditing Standard ASA 320. Materiality in Planning and Performing an Audit. Australian Government. Available online: https://www.auasb.gov.au/admin/file/content102/c3/ASA_320_Compiled_ 2015.pdf (accessed on 31 May 2021). 
AUASB (Auditing and Assurance Standards Board). 2015b. Auditing Standard ASA 315. Auditing Standard ASA 315. Identifying and Assessing the Risks of Material Misstatement through Understanding the Entity and Its Environment. Auditing and Assurance Standards Board. Australian Government. Available online: https://www.auasb.gov.au/admin/file/content102/c3/ASA_315_ Compiled_2015.pdf (accessed on 31 May 2021).

AUASB (Auditing and Assurance Standards Board). 2015c. Evaluation of Misstatements Identified during the Audit. Auditing Standard ASA 315. Auditing and Assurance Standards Board. Australian Government. Available online: https://www.auasb. gov.au/admin/file/content102/c3/ASA_450_Compiled_2015.pdf (accessed on 31 May 2021).

Bellandi, Francesco. 2018. Materiality in Financial Reporting. An Integrative Approach. Bingley: Emerald Publishing.

Bernstein, Leopold A. 1967. The Concept of Materiality. The Accounting Review 42: 86-95.

Blokdijk, Hans, Fred Drieenhuizen, Dan A. Simunic, and Michael T. Stein. 2003. Factors Affecting Auditors' Assessments of Planning Materiality. Auditing: A Journal of Practice \& Theory 22: 297-307. [CrossRef]

Boatsman, James R., and Jack C. Robertson. 1974. Policy-Capturing on selected Materiality Judgments. The Accounting Review 49: 342-52.

Bringselius, Louise. 2018. Efficiency, Economy and Effectiveness-But What about Ethics? Supreme Audit Institutions at a Critical Juncture. Public Money \& Management 38: 105-10. [CrossRef]

CAANZ (Chartered Accountants Australia New Zealand). 2021. Codes and Standards. Australian Professional and Ethical Standards Board (APES) 110—Codes of Ethics for Professional Accountants. Available online: https:/ /www.charteredaccountantsanz.com/ member-services / member-obligations / codes-and-standards (accessed on 20 May 2021).

Cameron, Jonathan. 2014. Applying the Materiality Concept: The Case of Abnormal Items. Corporate Ownership E Control 12: 427-37. [CrossRef]

Carpenter, Brian W., and Mark W. Dirsmith. 1992. Early Extinguishment Transactions and Auditor Materiality Judgements: A Bounded Rationality Perspective. Accounting, Organisations and Society 17: 709-39. [CrossRef]

Centre for Corporate Governance. 2016. Statement of Common Principles of Materiality of the Corporate Reporting Dialogue. Available online: https:/ / corporatereportingdialogue.com/wp-content/uploads/2016/03/Statement-of-Common-Principlesof-Materiality.pdf (accessed on 24 April 2021).

Chewning, Gene, Kurt Pany, and Stephen Wheeler. 1989. Auditor Reporting Decisions Involving Accounting Principle Changes. Some Evidence on Materiality Thresholds. Journal of Accounting Research 27: 78-96. [CrossRef]

Chewning, Eugene G., Jr., Stephen W. Wheeler, and Kam C. Chan. 1998. Evidence on Auditor and Investor Materiality Thresholds Resulting from Equity-for-Debt Swaps. Auditing: A Journal of Practice E Theory 17: 39-53.

Choudhary, Preeti, Kenneth Merkley, and Katherine Schipper. 2019. Auditors Quantitative Materiality Judgments: Properties and Implications for Financial Reporting Reliability. Journal of Accounting Research 57: 1303-51. [CrossRef]

Corporations Act. 2001. Corporations Act 2001. Federal Register of Legislation. Available online: https://www.legislation.gov.au/ Details/C2017C00328 (accessed on 19 May 2021).

CPAA CAANZ IPA (CPA Australia, Chartered Accountants Australia and New Zealand, and Institute of Public Accountants). 2015. Auditing Competency Standards for Registered Company Auditors. August. Available online: https://www.publicaccountants. org.au/media/628517/Auditing-Competency-Standard-FINAL-AUGUST-2015.pdf (accessed on 24 April 2021).

DeZoort, F. Todd, Dana R. Hermanson, and Richard W. Houston. 2003. Audit Committee Support for Auditors: The Effects of Materiality Justification and Accounting Precision. Journal of Accounting and Public Policy 22: 175-99. [CrossRef]

Dirsmith, Mark W., and John P. McAllister. 1982. The Organic vs. the Mechanistic Audit. Journal of Accounting, Auditing and Finance 5: 214-28.

Dye, Kenneth M., and Rick Stapenhur. 1998. Pillars of Integrity: The Importance of Supreme Audit Institutions in Curbing Corruption. Washington, DC: The Economic Development Institute of the World Bank; The International Bank of Reconstruction and Development/World Bank, Available online: https:/ / documents1.worldbank.org/curated/en/199721468739213038/pdf/multipage.pdf (accessed on 7 June 2021).

Edgley, Carla. 2014. A Genealogy of Accounting Materiality. Critical Perspectives on Accounting 25: 255-71. [CrossRef]

Eilifsen, Aasmund, and William F. Messier. 2015. Materiality Guidance of the Major Public Accounting Firms. Auditing: A Journal of Practice E Theory 3: 3-26. [CrossRef]

Elkington, John. 1997. Cannibals with Forks: The Triple Bottom Line of 21st Century Business, Capstone. Available online: http: / / www.trentglobal.edu.sg/wp-content/uploads/2017/01/Triple-Bottom-Line.pdf (accessed on 7 June 2021).

Farneti, Federica, and James Guthrie. 2009. Sustainability Reporting by Australian Public Sector Organisations: Why they Report? Accounting Forum 33: 89-98. [CrossRef]

FASB (Financial Accounting Standards Board). 1980. Statement of Financial Accounting Concepts No. 2. Status. Qualitative Characteristics of Accounting Information. Available online: https://www.fasb.org/jsp/FASB/Page/PreCodSectionPage\&cid= 1176156317989 (accessed on 24 April 2021).

Firth, Michael. 1979. Consensus Views and Judgment Models in Materiality Decisions. Accounting, Organisations and Society 4: $283-95$. [CrossRef]

Frishkoff, Paul. 1970. Empirical Investigation of the Concept of Materiality. Empirical Research in Accounting: Selected Studies. Journal of Accounting Research 8: 116-29. [CrossRef] 
GRI (Global Reporting Initiatives). 2021. The Global Standards for Sustainability Reporting. Available online: https://www. globalreporting.org/standards/ (accessed on 7 June 2021).

Holstrum, Gary L., and William F. Messier Jr. 1982. A Review and Integration of Empirical Research on Materiality. Auditing: A Journal of Practice \& Theory 2: 45-63.

Houghton, Keith A., Christine Jubb, and Michael Kend. 2011. Materiality in the context of an Audit: The Real Expectation Gap. Auditing: A Journal of Practice $\mathcal{E}$ Theory 26: 482-500. [CrossRef]

IAASB (International Auditing and Assurance Standards Board). 2018. ISA 320 Materiality in Planning and Performing an Audit. Available online: https:/ / www.ifac.org/system/files/downloads/a018-2010-iaasb-handbook-isa-320.pdf (accessed on 7 May 2021).

IAUSB (International Auditing and Assurance Standards Board). 2019. ISA 315 (Revised 2019) Identifying and Assessing the Risks of Material Misstatement. Available online: https:/ / www.ifac.org/system/files/publications/files/ISA-315-Full-Standard-andConforming-Amendments-2019-.pdf (accessed on 7 May 2021).

IAASB (International Auditing and Assurance Standards Board). 2020. ISA 220 (Revised). Quality Management for an Audit of Financial Statements. Available online: https:/ / www.ifac.org/system/files/publications/files/IAASB-International-StandardAuditing-220-Revised.pdf (accessed on 31 May 2021).

IASB (International Accounting Standards Board). 2021. IFRS Practice Statement 2: Making Materiality Judgements. Available online: https:/ / www.ifrs.org/issued-standards/list-of-standards/materiality-practice-statement/ (accessed on 31 May 2021).

ICAEW (Institute of Chartered Accountants England and Wales). 2017. Materiality in the Audit of Financial Statements. Available online: https:/ / www.icaew.com/- / media/corporate/files/technical/iaa/materiality-in-the-audit-of-financial-statements.ashx (accessed on 21 April 2021).

IFAC (International Federation of Accountants). 2009. International Accounting Standard on Auditing 320. Materiality in Planning and Performance Audit. Available online: https://www.ifac.org/system/files/downloads/a018-2010-iaasb-handbook-isa-320.pdf (accessed on 31 May 2021).

IFAC (International Federation of Accountants). 2011. ISAE 3000 (Revised), Assurance Engagements other than Audits or Reviews of Historical Financial Statements. International Auditing and Assurance Standards Board. Available online: https://www.ifac.org/ system/files/publications / exposure-drafts/IAASB_ISAE_3000_ED.pdf (accessed on 7 June 2021).

IFRS (International Financial Reporting Standards) Foundation. 2018. Definition of Materiality. Amendments to IAS 1 and IAS 8. IFRS Foundation. Available online: https://www.efrag.org/Assets/Download?assetUrl=\%2Fsites \%2Fwebpublishing $\% 2 F M e e t i n g \%$ 20Documents\%2F1709060818526684\%2F04-05\%20Definition\%20of\%20Material\%20-\%20Published\%20Amendments\%20-\%20 EFRAG\%20TEG\%2018-11-29.pdf\&AspxAutoDetectCookieSupport=1 (accessed on 11 June 2021).

IFRS (International Financial Reporting Standards) Foundation. 2021a. IAS (International Accounting Standards) 1 Presentation of Financial Statements. IFRS Foundation. Available online: https://www.ifrs.org/issued-standards/list-of-standards/ias-1presentation-of-financial-statements.html/content/dam/ifrs/publications/html-standards/english/2021/issued/ias1/ (accessed on 11 June 2021).

IFRS (International Financial Reporting Standards) Foundation. 2021b. IAS (International Accounting Standards) 8 Accounting Policies, Changes in Accounting Estimates and Errors. Available online: https://www.ifrs.org/issued-standards/list-of-standards/ias8-accounting-policies-changes-in-accounting-estimates-and-errors.html/content/dam/ifrs/publications/html-standards / english/2021/issued/ias8/ (accessed on 11 June 2021).

IIRC (International Integrated Reporting Council). 2021. Integrated Reporting. International Framework. Available online: https: // integratedreporting.org/resource/international-ir-framework/ (accessed on 19 May 2021).

INTOSAI. 2021. INTOSAI-International Organization of Supreme Audit Institutions. Available online: https://www.intosai.org/ (accessed on 6 June 2021).

INTOSAI (International Organization of Supreme Audit Institutions) Journal. 2021. New Code of Ethics Adopted. International Journal of Government Auditing Feature Articles. Available online: http:/ / intosaijournal.org/new-code-of-ethics-adopted/ (accessed on 7 June 2021).

Iselin, Errol R., and Takiah M. Iskandar. 2003. Auditors' Recognition and Disclosure Materiality Thresholds: Their Magnitude and Effects of Industry. The British Accounting Review 32: 289-309. [CrossRef]

Iskandar, Takiah Mohd, and Erol R. Iselin. 1999. A review of Materiality Research. Accounting Forum 23: 209-39. [CrossRef]

Jennings, Marianne, Dan C. Kneer, and Philip M. J. Reckers. 1987. A Reexamination of the Concept of Materiality: View of Auditors, Users, and Officers of the Court. Auditing: A Journal of Practice $\mathcal{E}$ Theory 6: 104-15.

Joyce, Edward J., and Robert Libby. 1982. Behavioural Studies on Audit Decision Making. Journal of Accounting Literature 1: 103-21.

Keune, Marsha B., and Karla M. Johnstone. 2009. Staff Accounting Bulletin No. 108 Disclosures: Descriptive Evidence from the Revelation of Accounting Misstatements. Accounting Horizon 23: 19-53. [CrossRef]

Keune, Marsha B., and Karla M. Johnstone. 2012. Materiality Judgements and the Resolution of Detected Misstatements: The Role of Managers, Auditors, and Audit Committees. The Accounting Review 87: 1641-77. [CrossRef]

Kristensen, Rikke Holmslykke. 2015. Judgement in an Auditor's Materiality Assessments. Danish Journal of Management E Business 79: 53-65.

Krogstad, Jack L., Richard T. Ettenson, and James Shanteau. 1984. Context and Experience in Auditors' Materiality Judgements. Auditing: A Journal of Practice \& Theory 4: 54-73. 
Martinov-Bennie, Nonna, and Peter Roebuck. 1998. The Assessment and Integration of Materiality and Inherent Risk: An Analysis of Major Firms' Audit Practices. International Journal of Auditing 2: 103-26. [CrossRef]

Mayper, Alan G. 1982. Consensus of Auditors' Materiality Judgements and Internal Accounting Control Weaknesses. Journal of Accounting Research 20: 773-83. [CrossRef]

Mayper, Alan G., Mary Schroeder Doucet, and Carl S. Warren. 1989. Auditors' Materiality Judgements of Internal Accounting Control Weaknesses. Auditing: A Journal of Practice $\mathcal{E}$ Theory 9: 72-86.

Messier, William. F. 1983. The effect of experience and firm type on materiality/disclosure judgements. Journal of Accounting Research 21: 611-18. [CrossRef]

Messier, William F., Nonna Martinov-Bennie, and Aasmund Eilifsen. 2005. A Review and Integration of Empirical Research on Materiality: Two Decades Later. Auditing: A Journal of Practice $\mathcal{E}$ Theory 24: 153-57. [CrossRef]

Monroe, Gary Stewart, and David Woodliff. 1993. An Empirical Investigation of the Audit Expectation Gap: An Australian Evidence. Accounting and Finance 34: 47-74. [CrossRef]

Moriarity, Shane, and F. Hutton Barron. 1976. Modeling the Materiality Judgements of Audit Partners. Journal of Accounting Research 14: 320-41. [CrossRef]

Moriarity, Shane, and F. Hutton Barron. 1979. A Judgement-Based Definition of Materiality. Journal of Accounting Research 17: 114-36. [CrossRef]

Nelson, Mark W., and Hun-Tong Tan. 2005. Judgement and Decision Making Research in Auditing: A Task, Person, and Interpersonal Interaction Perspective. Auditing: A Journal of Practice E Theory 24: 41-71. [CrossRef]

Nelson, Mark W., Steven D. Smith, and Zoe-Vonna Palmrose. 2005. The Effect of Quantitative Materiality Approach on Auditor's Adjustment Decision. The Accounting Review 80: 897-920. [CrossRef]

Neumann, Fred. 1968. The Auditing Standard of Consistency. Journal of Accounting Research 6: 1-17. [CrossRef]

$\mathrm{Ng}$, Terence Bu-Peow. 2007. Auditors' decision on audit differences that affect significant earnings thresholds. Auditing: A Journal of Practice $\mathcal{E}$ Theory 26: 71-89. [CrossRef]

Nicholls, Alex. 2018. A General Theory of Social Impact Accounting: Materiality, Uncertainty and Empowerment. Journal of Social Entrepreneurship 9: 132-53. [CrossRef]

Nogler, George, and John Armstrong. 2013. How Auditors Get into Trouble-How to Avoid It. Journal of Corporate Accounting \& Finance 24: 5-10. [CrossRef]

Patterson, Evelyn R., and Reed Smith. 2003. Materiality Uncertainty and Earnings Misstatement. The Accounting Review 78: 819-46. [CrossRef]

PCAOB (Public Company Accounting Oversight Board). 2021. Auditing Standard Number 11. Consideration of Materiality in Planning and Performing an Audit. Available online: https://pcaobus.org/oversight/standards/archived-standards/pre-reorganizedauditing-standards-interpretations/details/auditing-standard-no-11_1767 (accessed on 24 April 2021).

Pierre, Jon, and Jenny de Fine Licht. 2019. How do Supreme audit Institutions manage their Autonomy and Impact? A Comparative Analysis. Journal of European Public Policy 26: 226-45. [CrossRef]

Roberson, Brian K. 2005. Statement by SEC Staff: Remarks before the 2005 AICPA National Conference on Current SEC and PCAOB Developments. U.S. Securities and Exchange Commission. Available online: https://www.sec.gov/news/speech/spch12050 5bkr.htm (accessed on 24 April 2021).

SEC (U.S. Securities Exchange Commission). 1999. SEC Staff Accounting Bulletin: No 99-Materiality. Available online: https: / / www.sec.gov/interps/account/sab99.htm (accessed on 6 June 2021).

SEC (U.S. Securities Exchange Commission). 2005. Record of Proceedings. Securities and Exchange Commission Advisory Committee on Smaller Public Companies. Available online: https: / www.sec.gov/info/smallbus/acspc/acspctranscript092005.pdf (accessed on 11 June 2021).

SEC (U.S. Securities Exchange Commission). 2013. Report on Review of Disclosure Requirements in Regulation S-K. As Required by Section 108 of the Jumpstart Our Business Startups Act. Available online: https:/ /www.sec.gov/files/reg-sk-disclosurerequirements-review.pdf (accessed on 24 April 2021).

Siegel, Marc. 1980. For the Investor: Disclosure Effectiveness. How Materiality Fits In. FASB (Financial Accounting Standards Board). Available online: https: / /www.fasb.org/cs /ContentServer?c=Page\&cid=1176167771326\&d=\&pagename=FASB $\%$ 2FPage\%2FSectionPage (accessed on 24 April 2021).

Sims, Ronald R., and Johannes Brinkmann. 2003. Enron Ethics (Or: Culture Matters More Than Codes). Journal of Business Ethics 45: 243-56. [CrossRef]

Smith, Malcolm, Brenton Fiedler, Bruce Brown, and Joanne Kestel. 2001. Structure versus Judgement in the Audit Process: A Test of Kinney's Classification. Managerial Auditing Journal 16: 40-49. [CrossRef]

Smith, Frederick Hendrik, Francois Retief, and Reece Alberts. 2021. The evolving role of Supreme Auditing Institutions (SAIs) towards enhancing Environmental Governance. Impact Assessment and Project Appraisal 39: 67-79. [CrossRef]

Stapenhurst, Rick, and Jack Titsworth. 1991. Features and functions of Supreme Audit Institutions. Prem Notes. No. 59. Public Sector. The World Bank. Available online: http:/ / www1.worldbank.org/prem/PREMNotes/premnote59.pdf (accessed on 6 June 2021).

Steinbart, Paul J. 1987. The Construction of a Rule-Based Expert System as a Method for Studying Materiality Judgements. The Accounting Review 62: 97-116.

Stringer, Kenneth W. 1981. Future Directions in Auditing Research. The Auditor's Report Summer: 3-4. 
Sullivan, Jerry D. 1984. The Case for the Unstructured Audit Approach. Retrieved from University of Kansas. Available online: https: / / egrove.olemiss.edu/cgi/viewcontent.cgi?article=1157\&context=dl_proceedings (accessed on 24 April 2021).

U.S. Supreme Court. 1976. TSC Industries, Inc., Petitioners, v. Northway, Inc., Justia. U.S. Supreme Court. Available online: https://supreme.justia.com/cases/federal/us/426/438/ (accessed on 24 April 2021).

UNDP (United Nations Development Program). 2021. The SDGS in Action. What Are Sustainable Development Goals? Available online: https: / / www.undp.org/sustainable-development-goals (accessed on 7 June 2021).

Wang-On-Wing, Bernard, J. Hal Reneau, and Stephen G. West. 1989. Auditors' Perception of Management: Determinants and Consequences. Accounting, Organisations and Society 14: 577-87. [CrossRef]

Ward, Bart H. 1976. An Investigation of the Materiality Construct in Auditing. Journal of Accounting Research 14: 138-52. [CrossRef]

WASB (Water Accounting Standards Board). 2012. Australian Water Accounting Standard 1. Preparation and Presentation of General Purpose Water Accounting Reports. Bureau of Meteorology. Australian Government. Available online: http://www.bom.gov. $\mathrm{au} /$ water/standards/wasb/documents/Water-Accounting-Conceptual-Framework-Accessible.pdf (accessed on 20 May 2021).

Woolsey, Sam M. 1954. Development of Criteria to Guide the Accountant in Judging Materiality. Journal of Accountancy 97: 167-73. 